\title{
SMES PERSPECTIVE ON VENTURE CAPITAL INVESTMENT CRITERIA - A STUDY OF CROATIAN SMES
}

\author{
Marija Šimić Šarić
}

Received: 26. 8. 2016

Accepted: 28. 5. 2017

Preliminary communication

UDC 005.334-022.51/.55(497.5)

The importance of small and medium sized enterprises (SMEs) for the economy is indisputable. However, SMEs worldwide, including Croatian ones, have difficulties in accessing financing sources, primarily the alternative ones like venture capital. Seeking venture capital for entrepreneurs is a big challenge because of the absence of unique venture capital investment criteria and investment process. Less than $3 \%$ of the entrepreneurs succeed in attracting venture capital. In order to increase the chances of obtaining venture capital in the first phase, this study seeks to explain the required venture capital investment criteria from the perspective of SMEs. To the author's best knowledge, no studies have to date been undertaken specifically on venture capital investment criteria in Croatia. Final results suggest that that the SME manager/owner (manager/owner of SMEs) who seeks to attract venture capital is a male, aged between 35-44, has an BSc academic degree and the company is privately owned. Regarding the profile characteristics, the results show that, looking from the point of the SME manager/owner, goal orientation and hard work are the most important factors for seeking venture capital in the first phase, followed by innovation and reasonable risk-taking.

Keywords: Venture capital, SMEs, Croatia

\section{INTRODUCTION}

Thousands of entrepreneurs every year try to obtain the necessary capital for their companies from venture capitalists (Petty and Gruber, 2009). Submitting their business proposals, they hope to meet the venture capital requirements. However, about $60 \%$ of the proposals are rejected in the first phase and only less than $3 \%$ of the entrepreneurs succeed to attract venture

\footnotetext{
* Marija Šimić Šarić, PhD, Senior assistant, University of Split, Faculty of Economics, Cvite Fiskovića 5, 21000 Split, Croatia, E-mail:msimic@efst.hr
} 
capital (Norton, 1995, Hudson and Evans, 2005, Albers, 2006, Metrick and Yasuda, 2011, Visagie, 2011). Some of the reasons for that include the absence of a distinctly defined venture capitalists decision-making process (Hudson and Evans, 2005), venture capitalists not fully understanding their own decisionmaking process (Hudson and Evans, 2005, Zacharakis and Meyer, 1998), venture capitalists and entrepreneurs having different opinions on the investment readiness of companies for financing through venture capital (Proimos and Murray, 2006), subjective nature of the decision-making process (Cope et al. 2004), and the absence of uniquely defined investment criteria (Khanin et al., 2008). Consequently, the method of selecting companies for financing remains a difficult process both for entrepreneurs and business owners (Capasso et al., 2014).

According to Martel (2006), there is a considerable amount of research done on investment criteria: Wells (1974), Poindexter (1976), Ruby (1984), Tyebjee \& Bruno (1984), MacMillan et al. (1985), MacMillan et al. (1987), Siskos \& Zoponuidis (1987), Robinson (1987), Timmons et al. (1987), Hisrich \& Jankowicz (1990), Roure \& Keeley (1990), Dixon (1991), Hall \& Hoffer (1993), Rah et al. (1994), Fried \& Hisrich (1994), Muzyka et al. (1996), Boocock \& Woods (1997), Zacharakis \& Meyer (2000), Boehm (2002), Beim (2004), Kaplan \& Stromberg (2004) and Martel (2006), but not one of those studies has produced a unique solution. Furthermore, Khanin et al. (2008), Jell et al. (2010), Kollmann and Kuckertz (2010), Visagie (2011) Narayansamy et al. (2012) and Capasso et al. (2014) also raised the questions concerning the nature and importance of the investment criteria set by venture capitalists.

Although considerable research on venture capitalists' investment criteria have been undertaken, to the best of the author's knowledge, research focused on the profile characteristics of SMEs attracting venture capital in the first phase, does not exist. The purpose of this research is to identify these characteristics.

\section{SMEs - THEORETICAL REVIEW}

Academic researchers, governments and practitioners considered large companies crucial for economic growth till 1970s. It was thought that they were the key, the foundation of economic growth and the main source of job creation. However, in 1979, Birch with his work entitled "The Job Generation Process" directed the focuse of scientists and governments from large enterprises to SMEs, because the report stressed the higher contribution of SMEs to job creation compared to large enterprises (Kingombe et al., 2010). Despite vast 
Management, Vol. 22, 2017, 1, pp. 117-133

M. Šimić Šarić: SMEs perspective on venture capital investment criteria - A study of Croatian...

research on SMEs in the last twenty years, it is evident that the research is still in its infancy (Mac an Bhaird, 2010).

The problem of defining SMEs has existed since the first studies related to them. Today there is no general, global SME definition (Ata et al., 2013, Smit and Watkins, 2012, Mahembe, 2011, Ganbold, 2008, Fan, 2003, Tonge, 2001). Definitions slightly different from one country to the next, and they are primarily dependent on laws/acts of individual countries.

In the European union, a new definition of SMEs was implemented on 1 January 2005 (European Commission, 2006) and it reads as follows: "The category of micro, small and medium-sized enterprises (SMEs) is made up of enterprises which employ fewer than 250 persons and which have an annual turnover not exceeding 50 million euro, and/or an annual balance sheet total not exceeding 43 million euro“.

In Croatia, SMEs are defined according to the Accounting Law (Official Gazette, 109/07) and the Law on Small Business Encouragement (Official Gazette, 29/02, 63/07, 53/12, 56/13). SMEs are classified according to annual turnover, assets (balance sheet) and average number of employees. The classification for Croatia and European Union is given in Table 1.

Table 1. SMEs in Croatia and European Union

\begin{tabular}{|l|c|c|c|c|c|c|}
\cline { 2 - 7 } \multicolumn{1}{c|}{} & \multicolumn{3}{c|}{ Croatia } & \multicolumn{3}{c|}{ European Union } \\
\cline { 2 - 7 } \multicolumn{1}{c|}{} & Micro & Small & Medium & Micro & Small & Medium \\
\hline $\begin{array}{l}\text { Annual Work } \\
\text { Unit (AWU) }\end{array}$ & $<10$ & $<50$ & $<250$ & $<10$ & $<50$ & $<250$ \\
\hline $\begin{array}{l}\text { Annual } \\
\text { turnover } \\
\text { (million) }\end{array}$ & $<€ 2$ & $\leq € 10$ & $\leq € 50$ & $\leq € 2$ & $\leq € 10$ & $\leq € 50$ \\
\hline $\begin{array}{l}\text { Annual balance } \\
\text { sheet total } \\
\text { (million) }\end{array}$ & $<€ 2$ & $\leq € 10$ & $\leq € 43$ & $\leq € 2$ & $\leq € 10$ & $\leq € 43$ \\
\hline
\end{tabular}

Source: Author's compilation based on European Commission (2006) and the Law on Small Business Encouragement (Official Gazette, 29/02, 63/07, 53/12, 56/13).

It is common knowledge that SMEs are confronted with a wide range of problems. Figure 1 shows the obstacles for European Union and Croatia. Croatian SMEs are faced with a larger number of different barriers compared to EU SMEs. Those barriers include ineffectiveness of the legal system, deficiency of educational programs for entrepreneurship, underdevelopment of financial 


\section{Management, Vol. 22, 2017, 1, pp. 117-133}

M. Šimić Šarić: SMEs perspective on venture capital investment criteria - A study of Croatian...

markets for the satisfaction of SME sector needs, corruption, uncoordinated government policies in creating a favorable business climate etc. A highlyranked barrier both in the EU and in Croatia is access to finance. For Croatian SMEs additional problem is the underdevelopment of informal forms of financing like business angels or venture capital. It has often been pointed out that entrepreneurs in Croatia are not familiar with informal forms of financing and they do not know what the advantages and disadvantages are of these kinds of financing.

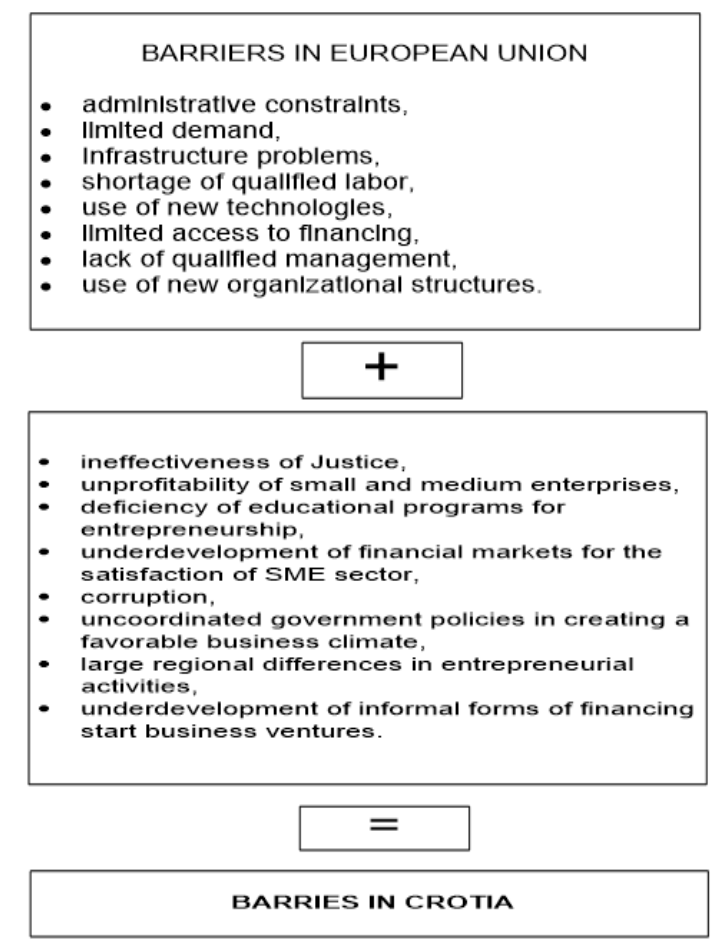

Figure 1. SMEs barriers in the EU and Croatia

Source: Author, according to Bistričić, Agatić and Kuzman (2011), Singet et al. (CEPOR, 2011), Kersan-Škabić and Banković (2008). 
Management, Vol. 22, 2017, 1, pp. 117-133

M. Šimić Šarić: SMEs perspective on venture capital investment criteria - A study of Croatian...

\section{VENTURE CAPITAL INVESTMENT CRITERIA - THEORETICAL BACKGROUND}

From the first research about venture capital in 1970s, investment criteria are in the focus of researchers worldwide. One question that remains in the focus of many researchers is this: What are the most important criteria that venture capitalists (VCs) take into account while making investment decisions?

The literature concerning venture capital investment criteria can be divided into two groups. One group are those who consider management characteristics as most important, while the other believe that the product/market are key for VCs decision making (Khanin et al., 2008). According to them some authors in different studies came to disparate opinions.

The seminal study by MacMillan et al. (1985) proposes six categories important to venture capitalists: the entrepreneur's personality, the entrepreneur's experience, characteristics of the product or service, characteristics of the market, financial consideration and the venture team. It also considers 27 investment criteria (Table 2). Five out of ten most important investment criteria are related to the experience or personality of the entrepreneurs. "There is no question that irrespective of the horse (product), horse race (market), or adds (financial criteria), it is the jockey (entrepreneur) who fundamentally determines whether the venture capitalist will place a bet at all".

Visagie (2011) concluded that ,decision making criteria employed by venture capitalists have been a source of fascination to many: entrepreneurs seeking funding, VCs seeking comparability and academics seeking wisdom". Kollmann and Kuckertz (2010) pointed out how different empirical studies emphasize the most important characteristics of the entrepreneur and the entrepreneurial team. Those authors state the following: "The influence of a management team's quality on venture performance is not merely a cliché popular with venture capitalists“. Except for company's ability to fulfill the requirements of $\mathrm{PE}$, so called equity- worthiness, for the successful finishing of the investment, company has to be motivated to accept an outside equity investor, demonstrating a, so called, equity - willingness (Capasso et al., 2014). 
Management, Vol. 22, 2017, 1, pp. 117-133

M. Šimić Šarić: SMEs perspective on venture capital investment criteria - A study of Croatian...

Table 2. Venture capital investment criteria

\begin{tabular}{|c|c|}
\hline \multirow{5}{*}{$\begin{array}{l}\text { I. The } \\
\text { entrepreneur's } \\
\text { personality }\end{array}$} & 1. Capable of sustained intense effort \\
\hline & 2. Able to evaluate and react to risk well \\
\hline & 3. Articulate in discussing venture \\
\hline & 4. Attends to detail \\
\hline & 5. Has a personality compatible with mine \\
\hline \multirow{5}{*}{$\begin{array}{l}\text { II. The } \\
\text { entrepreneur's } \\
\text { experience }\end{array}$} & 6. Thoroughly familiar with the market targeted by venture \\
\hline & 7. Demonstrated leadership ability in past \\
\hline & 8. Has a track record relevant to venture \\
\hline & 9. The entrepreneur was referred to me by a trustworthy source \\
\hline & 10. I am already familiar with the entrepreneur's reputation \\
\hline \multirow{4}{*}{$\begin{array}{l}\text { III. } \\
\text { Characteristics of } \\
\text { the product or } \\
\text { service }\end{array}$} & 11. The product is proprietary or can otherwise be protected \\
\hline & 12. The product enjoys demonstrated market acceptance. \\
\hline & $\begin{array}{l}\text { 13. The product has been developed to the point of a functioning } \\
\text { prototype }\end{array}$ \\
\hline & 14. The product may be described as "high tech" \\
\hline \multirow{5}{*}{$\begin{array}{l}\text { IV. } \\
\text { Characteristics of } \\
\text { the market }\end{array}$} & 15. The target market enjoys a significant growth rate. \\
\hline & 16. The venture will stimulate an existing market. \\
\hline & 17. The venture is an industry with which I am familiar. \\
\hline & 18. There is little threat of competition during the first three years. \\
\hline & 19. The venture will create a new market. \\
\hline \multirow{5}{*}{$\begin{array}{l}\text { V. Financial } \\
\text { considerations }\end{array}$} & $\begin{array}{l}\text { 20. I require a return equal to at least } 10 \text { times my investment within 5- } \\
10 \text { years. }\end{array}$ \\
\hline & $\begin{array}{l}\text { 21. I require an investment that can be easily made liquid (e.g., taken } \\
\text { public or acquired). }\end{array}$ \\
\hline & $\begin{array}{l}\text { 22. I require a return equal to at least } 10 \text { times my investment within at } \\
\text { least } 5 \text { years }\end{array}$ \\
\hline & 23. I will not be expected to make subsequent investments. \\
\hline & $\begin{array}{l}\text { 24. I will not participate in latter rounds of investment (requires my } \\
\text { participation in the initial round of investment). }\end{array}$ \\
\hline \multirow{4}{*}{$\begin{array}{l}\text { VI. The venture } \\
\text { team }\end{array}$} & $\begin{array}{l}\text { 25. The venture is initiated by one person with the relevant experience } \\
\text { to his idea. }\end{array}$ \\
\hline & $\begin{array}{l}\text { 26. The venture is initiated by more than one individual, each having } \\
\text { similar relevant experience. }\end{array}$ \\
\hline & $\begin{array}{l}\text { 27. The venture is initiated by more than one individual, the } \\
\text { individuals constituting a functionally balanced management team. }\end{array}$ \\
\hline & 28. None of the above is essential for the venture to go forward. \\
\hline
\end{tabular}

Source: MacMillan et al. (1985) 
According to Martel (2006) most studies about venture capital investment criteria were conducted in developed equity markets (Wells 1974, Poindexter 1976, Tyebjee and Bruno 1981, Tyebjee and Bruno 1984, MacMillan et al., 1985, MacMillan et al. 1987, Khan 1987, Sandberg et al. in 1988, Riquelme and Rikards 1992, Hall and Hofer 1993, Fried and Hisrich 1994, Boocock and Woods 1997, Zacharakis and Mayer 1998 and Shepherd 1999).

For emerging equity markets, small equity markets and economies in transition the number of studies is minor - only three studies (Martel, 2006). In those studies, the most common method of data collection is a questionnaire.

\section{ENTREPRENEURIAL CHARACTERISTICS}

While there is no single definition of entrepreneurs, we can define them as persons taking the initiative, patient and persistent, dedicated to their work, having exceptional organizational skills, ability to inspire people, to guide and control the business, committed to the attempt that all activities are performed following their unique vision. An entrepreneur can also be defined as a person who creates a business or product, manages resources, and takes the risk in order to make a profit, i.e. a person who organizes, manages, and assumes the risk of doing business in order to make profit (Siropolis, 1995, Buble and Kružić, 2006).

According to Hustedde and Pulver (1992), the success of attracting equity capital by entrepreneurs is associated with four universal variables:

- Characteristics of the entrepreneurs - education, experience and age;

- Characteristics of the enterprise - stage, industry type, and location;

- Characteristics of the request - amount, business plan, and prospective capital source;

- Source of advice - including technology, preparation of the business plan and a place to seek funds.

According to Cubico et al. (2010), entrepreneurial potential can be explained by following these factors:

- Factor 1: Goal orientation - tendencies towards creativity and innovation, degree of determination in reaching goals and personal perception as to overall handling of work situations.

- Factor 2: Leadership - aptitude for management and leadership.

- Factor 3: Adaptability - ability to perceive environmental change and adaptability. 
- Factor 4: Need for achievement - the desire for fame, success and social affirmation, as well as respect from others.

- Factor 5: Need for self-empowerment - the desire to realize oneself through one's job, which, apart from any economic goals, must be enjoyable, satisfying and interesting.

- Factor 6: Innovation - curiosity for what is new.

- Factor 7: Flexibility - tendency to reorient one's goals according to external situation.

- Factor 8: Autonomy - necessity of having one's own independent space to make decisions and choices.

According to Siropolis (1994), Buble and Kružić (2006), and Buble and Buble (2014), a successful entrepreneur should have the following traits:

- Innovation - innovative people are those who have a strong desire and willingness to tackle the unknown, want to do familiar things in new and unexpected ways, and offer good practical solutions;

- Reasonable risk-taking - possessing a "sixth sense" for risks and extreme courage and willingness to tackle those if and when they occur;

- Confidence - faith that they are better than others in their field, not reconciling with the existing state of things but trying to change;

- Hard work - person is a workaholic, but if the situation does not provide a challenge, they will tend to walk away from it;

- Goal orientation and responsibility - time and again setting new, higher goals and striving towards constant progress and development.

\section{STRUCTURE OF THE STUDY}

As stated previously, investment criteria set by venture capitalist are still an enigma, not just for the entrepreneurs, but also for the venture capitalists. Based on previous research about entrepreneurs' characteristics needed for attracting venture capital (MacMillan et al, 1985, Hustedde and Pulver, 1992, Siropolis, 1994, Buble and Kružić, 2006, Cubico et al., 2010, Buble and Buble, 2014), four characteristics of a potential successful entrepreneurs profile were selected as variables: innovation, reasonable risk-taking, hard work and goal orientation.

In the questionnaire designed for this research, five questions were related to the characteristics of the respondents and 16 questions referred to the characteristics of the profile of SMEs manager/owner (four questions for each variable). Most of the questions were close-ended questions and formulated 
according to the Likert-type scale with five degrees of intensity. The empirical research was based on data, collected by using a postal questionnaires, addressed to managers/owners of 58 small and medium sized Croatian companies, funded by venture capital. The sample list was collected personally, from a variety of secondary sources, as there is no database of companies financed by venture capital in Croatia.

A total of 29 usable questionnaires were received, which leads to the response rate of $50 \%$. This can seem quite a small sample, but, given the specificity of the research field, which is characterized by confidentiality of data, the return rate of $50 \%$ of the survey represents above-average return rate. Thus, it was decided that the reached response rate was adequate for conducting statistical analyses.

Collected data were processed by using Microsoft Excel and SPSS $17.0-$ Statistical Package for the Social Sciences (version 17.0) software. This processing resulted in: descriptive statistical analysis of the data collected, which included calculation of the mean values such as the mean, median, and mode, and the measures of dispersion around the mean values, i.e. standard deviation.

\section{RESEARCH RESULTS}

\subsection{General characteristics of respondents}

The company's size in this study is measured according to the criteria of the Law on Small Business Encouragement (Official Gazette, 29/02, 63/07, $53 / 12,56 / 13$ ). According to the guidelines set by this Law, entrepreneurs are classified as micro, small and medium subjects of SMEs according to these criteria: average number of employees, revenues and assets during the year. In the sample of 29 SMEs, $4(13.8 \%)$ are micro enterprises, 11 (37.9\%) are small and $14(48.3 \%)$ are medium size (Table 3$)$.

Table 3. Profile of respondents

\begin{tabular}{|l|c|c|c|c|}
\hline Size of company & Micro & Small & Medium & $\begin{array}{c}\text { Total (\% of } \\
\text { total) }\end{array}$ \\
\hline Total & $4(13.8 \%)$ & $11(37.9 \%)$ & $14(48.3 \%)$ & $29(100 \%)$ \\
\hline
\end{tabular}

Source: Research results. 
Management, Vol. 22, 2017, 1, pp. 117-133

M. Šimić Šarić: SMEs perspective on venture capital investment criteria - A study of Croatian...

Descriptive statistics for demographic characteristics of the company managers/owners (age. gender. academic degree and type of ownership) is shown below (Table 4). None of the managers/owners is under 24 , or over 59 , while the majority of the managers/owners are aged between 35 and 44 $(48.3 \%)$, which shows that the age structure of managers/owners can be considered as appropriate. Out of the total number of respondents $86.5 \%$ were male and $13.8 \%$ female; this is comparable to the Croatian entrepreneurship. being dominated by male entrepreneurs. In terms of the level of education. $82.6 \%$ of respondents have a university degree while $17.2 \%$ have high school education. Minor number of respondents have a $\mathrm{PhD}$ and $\mathrm{MSc}$ degree (just $3.4 \%$ ). Higher education degree does not seem critical for attracting venture capital. Out of the total number of respondents, the majority have a privatelyowned company (86.2\%) while there is no state, county and city-owned companies. Knowing how venture capital is always looking for dynamic companies, presented results are consistent with theoretical assumptions.

Table 4. Demographic statistics of respondents

\begin{tabular}{|c|c|c|c|c|c|}
\hline & & Frequency & Percent & $\begin{array}{c}\text { Valid } \\
\text { Percent }\end{array}$ & $\begin{array}{c}\text { Cumulative } \\
\text { Percent }\end{array}$ \\
\hline \multirow{4}{*}{ Age } & $25-34$ & 6 & 20,7 & 20,7 & 20,7 \\
\hline & $35-44$ & 14 & 48,3 & 48,3 & 69 \\
\hline & $45-59$ & 9 & 31 & 31 & 100 \\
\hline & Total & 29 & 100 & 100 & \\
\hline \multirow{3}{*}{ Gender } & Male & 25 & 86,2 & 86,2 & 86,2 \\
\hline & Female & 4 & 13,8 & 13,8 & 100 \\
\hline & Total & 29 & 100 & 100 & \\
\hline \multirow{6}{*}{ Academic degree } & $\begin{array}{l}\text { High } \\
\text { school }\end{array}$ & 5 & 17,2 & 17,2 & 17,2 \\
\hline & College & 3 & 10,3 & 10,3 & 27,6 \\
\hline & $\mathrm{BSc}$ & 19 & 65,5 & 65,5 & 93,1 \\
\hline & MSc & 1 & 3,4 & 3,4 & 96,6 \\
\hline & $\mathrm{PhD}$ & 1 & 3,4 & 3,4 & 100 \\
\hline & Total & 29 & 100 & 100 & \\
\hline \multirow{6}{*}{ Ownership } & Private & 25 & 86,2 & 89,3 & 89,3 \\
\hline & State & 0 & 0 & 0 & 0 \\
\hline & County & 0 & 0 & 0 & 0 \\
\hline & City & 0 & 0 & 0 & 0 \\
\hline & Others & 3 & 10,3 & 10,7 & 100 \\
\hline & Total & 28 & 96,6 & 100 & \\
\hline
\end{tabular}

Source: Research results. 


\subsection{Respondents' profiles}

Innovative people are those who have a strong desire and willingness to tackle the unknown, want to do familiar things in new and unexpected ways, they are interested in new things, and offer good practical solutions (Siropolis, 1994, Buble and Kružić, 2006, Cubico et al., 2010, Buble and Buble, 2014).

The respondents were asked to indicate their degree of agreement or disagreement with the closed - ended question on a five-point Likert-type scale ranging from 1 (strongly disagree) to 5 (strongly agree). Four closed - ended questions measure this variable. The value of the variable innovation is obtained as the average value of the average of the four questions. The descriptive statistics are presented in Table 5.

Table 5. Descriptive statistic for innovation

\begin{tabular}{|l|c|c|}
\hline \multicolumn{2}{|l|}{} & Innovation \\
\hline \multirow{2}{*}{$\mathbf{N}$} & Valid & 29 \\
\cline { 2 - 3 } & Missing & 0 \\
\hline Mean & 4.0776 \\
\hline Median & 4.0000 \\
\hline Std. Deviation & 0.72919 \\
\hline Minimum & 2.25 \\
\hline Maximum & 5.00 \\
\hline
\end{tabular}

Source: Research results.

Table 2 indicates that innovation is highly evaluated by managers/owners who attract venture capital. The value of median is 4 , compared to the maximum of 5 .

According to Siropolis (1994), Buble and Kružić (2006), Buble and Buble, (2014), reasonable risk-taking means owning a "sixth sense" for risks and extreme courage and willingness to tackle them if and when they occur. The respondents were asked to indicate their degree of agreement or disagreement with the closed - ended question on a five-point Likert-type scale ranging from 1 (strongly disagree) to 5 (strongly agree). Four closed - ended questions measure this variable. The value of the variable 'reasonable risk-taking' is obtained as the average value of the average of the four questions. The descriptive statistic for reasonable risk-taking is shown in Table 6 . The obtained results show that the characteristic 'reasonable risk-taking' is less important for 
Management, Vol. 22, 2017, 1, pp. 117-133

M. Šimić Šarić: SMEs perspective on venture capital investment criteria - A study of Croatian...

seeking venture capital in the first phase. Value of median is 3.5 (as compared to the scale maximum of 5).

Table 6. Descriptive statistic for reasonable risk-taking

\begin{tabular}{|c|c|c|}
\hline & & Reasonable risk-taking \\
\hline \multirow{2}{*}{$\mathbf{N}$} & Valid & 29 \\
\hline & Missing & 0 \\
\hline \multicolumn{2}{|c|}{ Mean } & 3.6866 \\
\hline \multicolumn{2}{|c|}{ Median } & 3.5000 \\
\hline \multicolumn{2}{|c|}{ Std. Deviation } & 0.76636 \\
\hline \multicolumn{2}{|c|}{ Minimum } & 1.50 \\
\hline \multicolumn{2}{|c|}{ Maximum } & 5.00 \\
\hline
\end{tabular}

Source: Research results.

Hard work might be described in terms of 'workaholism', but if the situation does not provide a challenge, it is not pursued (Siropolis, 1994, Buble and Kružić, 2006, Cubico et al., 2010, Buble and Buble, 2014). The respondents were asked to indicate their degree of agreement or disagreement with the closed - ended question on a five-point Likert-type scale, ranging from 1 (strongly disagree) to 5 (strongly agree). Four closed - ended questions measure this variable. The value of the variable 'hard work' is obtained as the average value of the average of the four questions. From Table 7, it is evident that hard work, as a characteristics of the manager/owner, is extremely important.

Table 7. Descriptive statistic for reasonable risk-taking

\begin{tabular}{|l|l|c|}
\hline \multicolumn{2}{|c|}{ Valid } & Reasonable risk taking \\
\hline \multirow{2}{*}{$\mathrm{N}$} & Missing & 29 \\
\cline { 2 - 3 } & Mean & 0 \\
\hline Median & 4.1724 \\
\hline Std. Deviation & 4.2500 \\
\hline Minimum & 0.68499 \\
\hline Maximum & 3.00 \\
\hline
\end{tabular}

Source: Research results.

According to Siropolis (1994), Buble and Kružić (2006), Cubico et al. (2010), and Buble and Buble (2014), goal orientation and responsibility stand 
for constantly striving to set higher goals, i.e., achieving constant progress and development, and personal perception as to overall handling of work situations. The respondents were asked to indicate their degree of agreement or disagreement with the closed - ended question on a five-point Likert-type scale ranging from 1 (strongly disagree) to 5 (strongly agree). Four closed - ended question measure this variable. The value of the variable 'goal orientation' is obtained as the average value of the average of the four questions and the median totals 4.25 , on the scale, with the maximum of 5 .

Table 8. Descriptive statistic for goal orientation

\begin{tabular}{|l|c|c|}
\hline \multicolumn{2}{|l|}{} & Goal orientation \\
\hline \multirow{2}{*}{$\mathbf{N}$} & Valid & 29 \\
\cline { 2 - 3 } & Missing & 0 \\
\hline Mean & 4.2903 \\
\hline Median & 4.2500 \\
\hline Std. Deviation & 0.50680 \\
\hline Minimum & 3.00 \\
\hline Maximum & 5.00 \\
\hline
\end{tabular}

Source: Research results.

According to research results, managers/owners of small and medium enterprises which attracted venture capital in Croatia considered goal orientation and hard work as the most important characteristics for seeking venture capital in the first phase. These characteristics are followed by innovation and reasonable risk taking.

\section{CONCLUSION}

Small and medium enterprises (SMEs) are confronted with a range of barriers when doing business. Croatian SMEs are faced with a larger number of different barriers compared to EU SMEs including ineffectiveness of the legal system, deficiency of educational programs for entrepreneurship, underdevelopment of financial markets for the satisfaction of SME sector needs, corruption, uncoordinated government policies in creating a favourable business climate etc. A commonly stressed and highly ranked barrier in the EU and Croatia is access to finance.

SMEs, especially in the early stages of development, have difficulties accessing necessary financial sources. As one option for filling this financial gap there is venture capital as an alternative source of finance. However, a 
common problem which occurs when SMEs attempt to seek venture capital is that about $60 \%$ of the business proposals are rejected in the first phase and only less than $3 \%$ of the entrepreneurs succeed in attracting venture capital. One of the most stated reasons for such a small percentage of investment is related to the fact that SMEs often do not satisfy the required investment criteria in the first phase.

Therefore, the aim of this research was to identify the SME manager/owner profile characteristics necessary to reach venture capital in the first phase. The results of the conducted research indicate that the SME manager/owner who attracts venture capital is a male, aged between $35-44$, has an BSc degree and his company is privately owned. Regarding the profile characteristics, the results show that, looking from the point of view of the SME manager/owner, goal orientation and hard work are the most important characteristics, followed by innovation and reasonable risk-taking.

Not involving companies that failed to attract venture capital can be highlighted as a potential limitation of this study. This is a challenge for further research, as there is no publicly available data. Secondly, the data are collected using survey data and, thus, are subject to the usual limitations associated with such data. Despite the potential limitations of the study, the fact remains that this is the first empirical study conducted on companies that attract venture capital in Croatia.

\section{REFERENCES}

1. Albers, J. (2006). Do You Have an Investable Business Case? Your Story Versus What VCs Really Want to Hear. Excell Partners, Inc., New York,112. http://preseedworkshop.com/documents/PDF-WP3-InvestableBusCase092506F.pdf [Accessed on March, 19, 2010].

2. Ata, A., Shukla, M., Singh, M. (2013). Financing SME Supply Chains. Swift institute working paper No. 2012-002. Malaysia Institute for Supply Chain Innovation and MIT global scale network.

3. Bistričić, A., Agatić, A., Kuzman, Z. (2011). Značaj poslovanja malih i srednjih poduzeća u gospodarstvu Republike Hrvatske i gospodarstvima zemalja Europske unije. Scientific Journal of Maritime Research, 25 (1), 145-158.

4. British Bankers Association. Banks' support for SMEs - Quarter 220131 , https://www.bba.org.uk/news/statistics/sme-statistics/banks-support-forsmes-quarter-2-2013/\#.VSecQvmsVHU [Accessed November 26, 2013]. 
Management, Vol. 22, 2017, 1, pp. 117-133

M. Šimić Šarić: SMEs perspective on venture capital investment criteria - A study of Croatian...

5. Buble, M., Kružić, D. (2006). Poduzetništvo - realnost sadašnjosti i izazov budućnosti. RRiF Plus, Zagreb.

6. Buble, M., Buble, M. (2014). Poduzetništo. Aspira, Redak d.o.o, Split.

7. Capasso, A., Faraci, R., Picone, P. M. (2014). Equity - worthiness and equity-willingness: Key factors in private equity deals, Business Horizons 57, pp. 637-645.

8. Cope, J., Cave, F., Eccles, S. (2004). Attitudes of Venture Capital Investors Towards Entrepreneurs with Previous Business Failure. School Working Paper 2004/017, Lancaster University Management. Companies Act 2006. United Kingdom, http://www.legislation.gov.uk/ukpga/2006/46/pdfs/ ukpga_20060046_en.pdf [Accessed November 26, 2013].

9. Cubico, S., Bortolani, E., Favretto, G, Sartoti, R. (2010). Describing the entrepreneurial profile: The entrepreneurial aptitude test (TAI), Int. J. Entrepreneurship and Small Business, 11 (4), pp. $424-435$.

10. European Commission (2006). The new SME definition, User guide and model declaration, http:/ec.europa.eu/enterprise/policies/sme/files/ sme_definition/sme_user_guide_en.pdf; [Accessed December 16, 2009].

11. Fan, Q. (2003). Importance of SMEs and the Role of Public Support in Promoting SME Development. World Bank. A Policy Dialogue Workshop, St. Petersburg.

12. Ganbold, B. (2008). Improving Access to Finance for SME: International Good Experiences and Lessons for Mongolia. IDE-JETRO, No 438.

13. Hudson, E., Evans, M. (2005). A Review of Research into Venture Capitalists' Decision Making: Implications for Entrepreneurs, Venture Capitalists and Researchers. Journal of Economic and Social Policy, 10 (1), pp. 1-18.

14. Hustedde, R. J., Pulver, G. C. (1992). Factors affecting equity capital acquisition: The demand side. Journal of Business Venturing, 7 (5), pp. 363-374.

15. Jell, F., Block, J. H., Henkel, J. (2010). Innovativität als Kriterium bei Venture Capital-Investitionsentscheidungen. Kredit und Kapital, 44 (4), pp. 509-541.

16. Kersan-Škabić, I., Banković, M. (2008). Malo gospodarstvo u Hrvatskoj i ulazak u Europsku uniju. Ekonomska misao i praksa, XVII (1), pp. 57-76.

17. Khanin, D., Baum J. R., Mahto, R. V., Heller, C. (2008). Venture Capitalists' Investment Criteria: 40 Years of Research. Small Business Institute Research Review, 35, pp. 187-192.

18. Kingombe, Ch., Bateman, M., te Velde, D.W. (2010). Review of the most recent literature on Entrepreneurship and SMEs, Overseas Development Institute. 
19. Kollmann, T., Kuckertz, A. (2010). Evaluation uncertainty of venture capitalist' investments criteria. Journal of Business Research, 63, 741-747.

20. Mac an Bhaird, C. (2010). Resourcing Small and Medium Sized Entreprises, A Financial Growth Life Cycle Approach. Springer - Verlag Berlin Heidelberg.

21. MacMillan, I. C., Siegel, R., Subba Narasimha, P. N. (1985). Criteria used by venture capitalists to evaluate new venture proposals. Journal of Business Venturing, 1, pp. 19-128.

22. Mahembe, E. (2011). Literature Review on Small and Medium Enterprises' Access to Credit and Support in South Africa, http://www.ncr.org.za/pdfs/ Literature\%20Review\%20on\%20SME\%20Access\%20to\%20Credit $\% 20$ in \%20South\%20Africa_Final\%20Report_NCR_Dec\%202011.pdf [Accessed May 19, 2013]

23. Martel, F. (2006). Venture Capitalists' Investment Process, Criteria, and Performance. University of Lausanne's Hautes Etudes Commerciales.

24. Metrick, A., Yasuda, A. (2011). Venture Capital \& the Finance of Innovation. 2nd ed. New York: Wiley.

25. Narayansamy, Ch., Hashemoghli, A., Rashid, R. M. (2012). Venture Capital Pre-Investment Decision Making Process: An Exploratory Study in Malaysia, Global Journal of Business Research, 6 (5), pp. 49-63.

26. Norton, E. (1995). Venture capital as an alternative means to allocate capital: an agency-theoretic view. Entrepreneurship: Theory and Practice. $\mathrm{http} / / \mathrm{www}$.allbusiness.com/business-finance/equity-funding-private-equity venture/589397-1.html; [Accessed September 2, 2010]

27. Petty, J. S., Gruber, M. (2009). In pursuit of the real deal: A longitudinal study of VC decision making. Journal of Business Venturing, doi:10.1016/j.jbusvent.2009.07.002, pp. 1-17.

28. Proimos, A., Murray, W. (2006). Entrepreneuring into Venture Capital. The Journal of Private Equity, 9 (3), pp. 23-34.

29. Singer, S. et al. (2011). Izvješće o malim i srednjim poduzećima u Hrvatskoj 2011. Cepor, Zagreb.

30. Siropolis, N. C. (1995). Menedžment malog poduzeća. IV. ed, MATE, Hrvatska obrtnička komora, Zagreb.

31. Smit, Y., Watkins, A. J. (2012). A literature review of small and medium enterprises (SME) risk management practice in South Africa. African Journal of Business Management, 6 (21), pp. 6324-6330.

32. The Official Gazette of Republic of Croatia (2007). Accounting Law, $\mathrm{http} / / /$ narodne-novine.nn.hr/clanci/sluzbeni/329423.html [Accessed on May 15, 2011] 
Management, Vol. 22, 2017, 1, pp. 117-133

M. Šimić Šarić: SMEs perspective on venture capital investment criteria - A study of Croatian...

33. The Official Gazette of Republic of Croatia (2013). Law on Small Business Support, $\quad \mathrm{http} / / / \mathrm{www} . z a k o n . h r / \mathrm{z} / 527 /$ Zakon-o-poticanju-razvoja-maloggospodarstva [Accessed on May 8, 2015]

34. Tonge, J.(2001). A Review of Small Business Literature, Part 1: Defining The Small Business. Working paper. Manchester Metropolitan University Business School Working Paper Series.

35. Visagie, I. (2011). Venture Capital Investment Criteria, An analysis of criteria and their relative importance. Business Master Project, Cass Business School, City University London.

36. Zacharakis, A. L., Meyer, G. D. (1998). A lack of insight: Do Venture Capitalists really understand their own decision process? Journal of Business Venturing, 13, pp. 57-76.

\title{
KRITERIJI ZA INVESTICIJU RIZIČNOG KAPITALA IZ PERSPEKTIVE MALIH I SREDNJIH PODUZEĆA (MSP) - ISTRAŽIVANJE HRVATSKIH MSP
}

\begin{abstract}
Sažetak
Važnost malih i srednjih poduzeća (MSP) za gospodarstvo je neupitna. Međutim, MSP širom svijeta, uključujući i hrvatska, imaju poteškoća u pristupu adekvatnim izvorima financiranja, prvenstveno alternativnim izvorima poput rizičnog kapitala. Pristup rizičnom kapitalu za mnoge poduzetnike je veliki izazov zbog nepostojanja jedinstveno definiranih investicijskih kriterija rizičnog kapitala, kao ni investicijskog procesa. Tek nešto manje od $3 \%$ poduzetnika ostvare financiranje putem rizičnog kapitala. S ciljem povećanja mogućnosti privlačenja rizičnog kapitala u prvoj fazi, ovo istraživanje nastoji objasniti investicijske kriterije rizičnog kapitala potrebne za privlačenje rizičnog kapitala od strane MSP-a. Konačni rezultati pokazuju kako menadžer/vlasnik MSP-a koji je uspio privući rizični kapital ima između 35 i 44 godine, muškog je spola, fakultetski je obrazovan, a poduzeće je u privatnom vlasništvu. Vezano uz karakteristike profila, rezultati pokazuju da su, gledajući s aspekta menadžera/vlasnika MSP-a, postavljanje ciljeva i uporan rad najvažnije karakteristike, a slijede inovativnost i razumno preuzimanje rizika.
\end{abstract}

Ključne riječi: rizični kapital, MSP, Hrvatska 

